\title{
Immunoreactivity of estrogen receptor alpha in brain and ovary of the short mackerel Rastrelliger brachysoma (Bleeker, 1851)
}

\author{
Sinlapachai Senarat ${ }^{\mathrm{a}}$, Jes Kettratad ${ }^{\mathrm{a}, \mathrm{b}^{*}}$, Niwat Kangwanrangsan ${ }^{\mathrm{c}}$, Wannee Jiraungkoorskul, \\ Francis Gerald Plumley ${ }^{\mathrm{a}}$, Masafumi Amano ${ }^{\mathrm{d}}$, Akio Shimizu ${ }^{\mathrm{e}}$, Piyakorn Boonyoung ${ }^{\mathrm{f}}$, Gen Kaneko ${ }^{g}$ \\ aDepartment of Marine Science, Faculty of Science, Chulalongkorn University, Bangkok 10330, Thailand \\ ${ }^{b}$ Center of Excellence for Marine Biotechnology (CEMB), Department of Marine Science, Faculty of Science, Chulalongkorn University, Pathum \\ Wan, Bangkok, 10330 Thailand \\ 'Department of Pathobiology, Faculty of Science, Mabidol University, Bangkok 10400, Thailand \\ ${ }^{d}$ School of Marine Biosciences, Kitasato University, Sagamihara, Kanagawa 252-0373, Japan \\ ${ }^{-}$National Research Institute of Fisheries Science, Fukuura 2-12-4, Kanazawa, Yokohama, 236-8648, Japan \\ Department of Anatomy, Faculty of Science, Price of Songkla University, Songkbla, 90110, Thailand \\ school of Arts and Sciences, University of Houston-Victoria, 3007 N. Ben Wilson St. Victoria, Texas 77901, USA
}

Received 27th February 2019 / Accepted 23rd June 2019

\begin{abstract}
The reproductive physiology concerning the gonadotropin hormone $(\mathrm{GTH})$ and its downstream target estrogen receptor alpha $(\mathrm{ER} \alpha)$ is not well understood in the short mackerel Rastrelliger brachysoma, an economically important marine fish in Thailand. In this study, we tested the hypothesis that the expression of both GTH and ER $\alpha$ in the brain and ovary of R. brachysoma was as reported in other fish species. By applying immunohistochemical techniques, we identified the distribution of $E R \alpha-$ immunoreactive (ir) neurons in the brain and ovary of wild female $R$. brachysoma during the spawning season along with the distribution of GTHs-ir cells in the ovary. The nucleus lateralis tuberis in the diencephalon had a high number of ER $\alpha$-ir neurons. In the mesencephalon, dense ER $\alpha$-ir neuronal fibers were mainly found in the mesencephalic cells, stratum opticum, stratum fibrosum et griseum superficiale and stratum album centrale. Both the valvula and corpus cerebelli in the metencephalon contained ER $\alpha$ ir neurons in granular and Purkinje cell layers as well as the molecular layer. The ER $\alpha$-ir neurons were also observed in the medulla oblongata. In the ovary, weak ER $\alpha$ and moderate GTHs immunoreactivities were observed in follicular cells of oocytes in early and late vitellogenic stages. This information provides baseline data required to understand not only the activity of estrogen $\left(\mathrm{E}_{2}\right)$ on the brain but also the regulatory mechanism of the hypothalamo-pituitary-ovarian axis of R. brachysoma.
\end{abstract}

Keywords: central nervous system, estrogenic receptor, oogenesis, short mackerel

\section{INTRODUCTION}

Gonadotropin-releasing hormone $(\mathrm{GnRH})$ is a hypothalamic hormone known to play important roles in reproductive activity in various animals including fish. This hormone from scombrids, often called seabream GnRH (sbGnRH), has been an important target of aquatic research since the Family Scombridae contains many aquaculture species such as Scomber japonicus Houttuyn, 1782 (Selvaraj et al., 2009) and Rastrelliger brachysoma (Bleeker, 1851) (Senarat, 2015; Senarat et al., 2019). In R. brachysoma, sbGnRH-immunoreactive (ir) neurons are present in three areas of the brain including nucleus periventricularis, nucleus preopticus and

\footnotetext{
*Author for correspondence: Jes Kettratad, Department of Marine Science, Faculty of Science, Chulalongkorn University, Bangkok, Thailand 10330. Email-Jes.K@chula.ac.th
} 
nucleus lateralistuberis (Senarat, 2015; Senarat et al., 2018). The sbGnRH-ir neuronal fibers project to the proximal pars distalis of the pituitary where gonadotropin hormone (GTH), specifically follicular stimulating hormone $(\mathrm{FSH})$ and luteinizing hormone $(\mathrm{LH})$, are produced (Senarat, 2015; Senarat et al., 2018). These observations are consistent with those from other teleosts such as Sparus aurata Linnaeus, 1758 (Gothilf et al., 1997), Dicentrarchus labrax (Linnaeus, 1758) (GonzálezMartínez et al., 2001; González-Martínez et al., 2002) and other fishes (Guilgur et al., 2006; Palevitch et al., 2009). Given the well-known function of GTH to control the activity of the gonadal sex steroid hormone estrogen in teleosts (Huggard-Nelson et al., 1996; Huggard-Nelson et al., 2002), it must be reasonable to assume that the oocyte differentiation of $R$. brachysoma female is also under control of the hypothalamo-pituitarygonad axis (HPG axis). Further clarification of the HPG axis will contribute to the establishment of efficient and sustainable aquaculture of this species.

Natural estrogens include estrone $\left(\mathrm{E}_{1}\right), 17 \beta$ estradiol $\left(\mathrm{E}_{2}\right)$ and estriol $\left(\mathrm{E}_{3}\right)$, and $\mathrm{E}_{2}$ plays a particularly important role in the gonadal development and uptake of vitellogenin into oocytes (Gustafsson, 2003; Hess, 2003; Heldring et al., 2007; Hara et al., 2016; Liu et al., 2017) via nuclear estrogen receptors (ERs) (Auchus and Fuqua 1994; Fukumoto et al., 2013; Tsai and O'Malley, 1994). There are three reported isoforms of ER, namely ER $\alpha, E R \beta$ and ER $\gamma$ (Sabo-Attwood et al., 2004; Nagler et al., 2012), and only $\mathrm{ER} \alpha$ is known to have a high affinity to estrogens in the ovary. The expression of ER $\alpha$ has been detected in the ovary of the rainbow trout Oncorbynchus mykiss (Richardson, 1836), indicating that estrogens regulate the oogenenic development via ER $\alpha$ in this species (Nagler et al., 2012). Interestingly, $E R \alpha$ has been also detected in the brain, especially the anterior preoptic area and the ventrolateral hypothalamus (Anglade et al., 1994; Forlano et al., 2005). It is therefore likely that estrogens exert a direct action on the brain via $E R \alpha$, creating a feedback loop to regulate the gonadal development (Anglade et al., 1994; Bouma and Nagler, 2001; Radovick et al., 2012).

The purpose of research reported here is to investigate the brain histology in mature $R$. brachysoma along with the identification of $\mathrm{ER} \alpha$ expression patterns in its brain. Additionally, the distribution of $E R \alpha$ - and GTHs-ir cells was determined in the ovary of $R$. brachysoma. This information provides baseline data required to understand not only the brain histology, but also an important role of $E_{2}$ on the brain and mature ovary of $R$. brachysoma.

\section{MATERIALS AND METHOD}

Fish collection. Sexually mature Rastrelliger brachysoma females ( $\mathrm{n}=56$ for brain and ovarian histology; 5 out of 56 were used for immunohistochemistry), approximately $17-18 \mathrm{~cm}$ in total length $(17.4 \pm 0.65 \mathrm{~cm}$ in standard length, mean \pm standard deviations) and 70-76 $\mathrm{g}$ in total weight (average $74.55 \pm 2.81 \mathrm{~g}$ ) were collected by bamboo strake trap from Samut Songkhram Province in the Upper Gulf of Thailand during the spawning season January to February 2014 (Senarat, 2015; Senarat et al., 2016)] (13¹6'18.4" $\left.\mathrm{N}, 100^{\circ} 02^{\prime} 13.4^{\prime \prime} \mathrm{E}\right)$. The main environmental factors related to reproductive activity are salinity and temperature (Senarat, 2015). During breeding season, the average ambient salinity was $31.75 \mathrm{ppt}$ whereas the average temperature was $29.05^{\circ} \mathrm{C}$ (Senarat, 2015). All fish were euthanized by rapid cooling shock (Wilson et al., 2009), and subsequently the brain and ovarian tissues were collected in field. In order to confirm that our specimens are fully mature, gonadosomatic indices (GSI) were calculated using the following formula (GSI $=$ [gonadal weight $/$ total weight $\mathrm{x}$ 100]). All organs were kept in Davidson's solution for further histological analyses. The protocols used in this study were approved by the Animal Care and Use Committee of the Faculty of Science, Chulalongkorn University, Thailand (Protocol Review No. 1423003).

\section{Histological and histochemical observations of the brain, pituitary gland and mature ovary.} Brain (telencephalon, diencephalon, mesencephalon, metencephalon and myelencephalon), pituitary gland and ovary were fixed in Davidson's fixative for about 24 hours at room temperature. After fixation, tissues were dehydrated through a graded series of ethyl alcohol and embedded in paraffin. Serial 4-5 $\mu \mathrm{m}$ 
sections were cut by a rotary microtome. Finally, the serial longitudinal, horizontal and cross sections on all samples were stained with Harris's hematoxylin and eosin (H\&E), and histochemically stained with Masson's trichrome (MT) and Periodic Acid-Schiff (PAS) (Bancroft and Gamble 2008). Brain sections were investigated for the histological structure and cellular composition, whereas ovary sections were examined for oocyte development under a light microscope following the guidelines by Dietrich and Krieger (2009) and Uribe et al. (2012). All tissue sections were photographed with a Leica DM1000 light microscope. Schematic diagrams of the pituitary gland were drawn by using Adobe Illustrator (version CS6).

\section{Tissue preparation and immunohisto-} chemistry. For immunohistochemical analyses, histological sections of $R$. brachysoma $(n=5)$ were mounted on poly-L-lysine coated slides. Brain $(\mathrm{ER} \alpha)$ and ovarian $[\mathrm{ER} \alpha$ and GTHs (follicular stimulating hormone (FSH) and luteinizing hormone $(\mathrm{LH})]$ sections were deparaffinized, rehydrated and treated in $10 \mathrm{M}$ citrate buffer (epitope-unmasking solution) for antigen retrieval. The sections were blocked for endogenous peroxidase with $3 \% \mathrm{H}_{2} \mathrm{O}_{2}$ in $30 \%$ methanol for $3 \mathrm{~min}$. Non-specific binding of proteins were blocked by incubating the section in a blocking solution ( $2 \%$ normal goat serum at room temperature for $30 \mathrm{~min}$ for $\mathrm{ER} \alpha$ and $10 \%$ normal goat serum $+4 \%$ BSA in 1 M PBS for 2 hours for GTHs). The sections were then incubated with following rabbit primary antisera: $\mathrm{ER} \alpha(1: 100)$ (Thermo Scientific, Waltham, MA), anti-Fundulus heteroclitus (Fh) FSH $\beta$ 50-60 or antiFh LH $\beta$ (1:1000 and 1:2000 in 0.1 M PBS) for overnight at $4^{\circ} \mathrm{C}$. After three washes in $0.1 \mathrm{M}$ PBS, sections were incubated with Envision ${ }^{\text {TM }}$ anti-rabbit $\operatorname{IgG}(\mathrm{ER} \alpha$; dilution 1:100; Thermo Scientific) or biotinylated goat anti-rabbit $\operatorname{IgG}$ solution (GTHs, dilution 1:500) for $30 \mathrm{~min}$. Immunoreactive cells were visualized with 3,3'diaminobenzidin (DAB) solution (Vector Laboratories, Burlingame, CA) and counterstained with Mayer's hematoxylin. The distribution of immunoreactive cells was observed and digital images were captured with a Leica digital 750 digital camera (Leica, Heidelberg, Germany). Distributions of GTHs- immunoreactive cells were also confirmed by immunofluorescent staining, which used Alexa 488-conjugated goat anti-rabbit IgG (Molecular Probes, Eugene, OR) as the secondary antibody at a dilution of 1:500 in blocking solution. These sections were washed and mounted in VECTA shield fluorescence mounting medium (Vector Laboratories) and then images were captured using a confocal laser scanning microscope (Olympus FV 1000; Olympus, Tokyo, Japan).

Positive and negative controls. In order to confirm the specific binding of antibody, positive and negative controls experiments were conducted. Standard tissue sections from breast cancer donated from the Songklanagarind hospital, Thailand, were used as the positive control for $E R \alpha$ because of the well-accepted presence of $E R \alpha$ in breast cancer cells. The negative control sections were processed in the same way except for the primary antibodies being replaced with pre immune sera.

Semiquantitative scoring and staining intensity. The staining intensities in the ovarian tissue were assessed by visual observation with following scores: - No immunoreactivity, + weak immunoreativity, ++ moderate immunoreactivity and +++ strong immunoreactivity. At the same time, the intensity value of immunostaning was measured from three slides/10 areas/sample by an automated cellular image analysis system, Digimizer software, version 3.7.0. The grade of intensity was divided into 4 categories: Negative (1.00), weak intensity (0.720-0.999), moderate intensity (0.292-0.719) and strong intensity (0.000.291 ), as following the standard guideline of Qasi et al. (2011).

\section{RESULTS AND DISCUSSION}

Gravimetric analysis and ovarian
development. Wild female $R$ brachysoma
collected during the spawning season had an
average GSI value of $1.65 \pm 0.15$ (mean \pm SD).
The ovarian developmental stage of our
specimens was considered to be the late
developmental stage, which comprised of
prominent secondary growth oocytes. The


secondary growth oocytes were characterized by reddish-stain with acidophilic staining due to the accumulation of yolk deposition in the ooplasm. Large lipid globules were also observed in Crenichthys baileyi and Empetrichthys latos (Uribe et al., 2012).

\section{Histological organization of $R$. brachysoma}

brain. Five major regions of the brain (telencephalon, diencephalon, mesencephalon, metencephalon and myelencephalon) have been previously described in R. brachysoma (Senarat et al., 2016). However, the location of the diencephalon in the pituitary gland under transverse serial sections was not reported in detail in the earlier report (Senarat et al., 2016). Prior to analyzing the protein distribution by immunohistochemistry, in this study, we further identified three nuclei in the diencephalon using detailed histological analyses on the brain of wild specimens $(\mathrm{n}=56)$ : The nucleus periventricularis, nucleus preopticus and nucleus lateralis tuberis. Based on the MT and PAS staining methods, neuronal populations in the nucleus preopticus-periventricularis were clearly distinguished from glial cells and were classified into three groups of different sizes: Small, medium and large (Figures 1A, 1B, 1D, 1F). The diameter of these neurons (calculated from randomly selected 10 cells per section) were 7.84 $\pm 0.26 \mu \mathrm{m}, 30.6 \pm 2.11 \mu \mathrm{m}$ and $50.9 \pm 1.36 \mu \mathrm{m}$, respectively (mean $\pm \mathrm{SD}$ ). On the other hand, the glial cells represented the most abundant cells, which were distinguished from neurons by their small nuclei and surrounded by eosinophilic cytoplasm (Figures 1D and 1F).

The nucleus periventricularis (NPI) was located in the ventral part of the hypothalamus (Figures 1B and 1C). Only small neurons arranged in 12-15 layers were found in this region. The nucleus preopticus $(\mathrm{Np})$ was located at the ventro-lateral region of the mesencephalon, where medium- and large-sized neurons were observed (Figures 1D and 1E). The nucleus lateralis tuberis (NLT) was found at the inferior lobe of the hypothalamus (i.e., in the ventral part of the nucleus periventricularis). The sagittal plane of this structure contained neurons of all sizes (small, medium and large; Figures $1 \mathrm{~F}$ and $1 \mathrm{G}$ ). A previous observation showed that all populations were positively reacted with anti-GnRH-like peptide antibody in R. brachysoma (Senarat et al.,
2019), and at present it is unclear how the functions of these three neuronal populations are different. Since these three nuclei are important regions for $\mathrm{GnRH}$ production in $\mathrm{R}$. brachysoma (Senarat et al., 2019) as well as other fishes (Peter et al., 1991; Palmieri et al., 2008), further investigation on these three types of neurons are required.

The pituitary gland was located within the diencephalon and it appeared to be attached to the ventral region of the hypothalamus. The overall histological structure of the pituitary gland of $R$. brachysoma consisted of two components: the adenohypophysis and the neurohypophysis. The adenohypophysis consisted of a cluster of cells and also divided into three distinguishable areas; the rostral pars distalis, the proximal par distalis and the pars intermedia (Figure 2 and schematic diagram 2A). Furthermore, penetration of the neurohypophysial process to the adrenohypophyseal area was observed. The identification of cell types in the adrenohypophysis using H\&E, MT, and PAS staining methods did not easily identify the level of hormones in each cell. However, these methods could classify the pituitary cells into four types: acidophil I, acidophil II, basophil and chromophil, each of which had different distributions in the adrenohypophyseal area (Figures 2B and 2J). Acidophil I and II cells were the major component in rostral par distalis. The acidophil I cells were stained in red-orange and were mainly located in the border of the neurohypophysis; they had oval shape nuclei. The acidophil II cells were relatively small when compared with acidophil I. These cells were localized in the central - ventral parts of RPD. They had spherical nuclei and were stained in red in the MT stain. The acidophil I, II and basophil cells were commonly observed in proximal par distalis. It is well known that basophils are considerably homologous to the somatotrope and gonadotrope, as previously described in other teleosts (Shimizu et al., 2003; Yan and Thomas, 1991). The important role of gonadotrope is to produce GTHs (Shimizu et al., 2003). Hence, the activity of estrogens could play a crucial role in the regulation via ER receptor for estrogen feedback. This pathway then controls LH secretion in the pituitary gland (Gieske et al., 2008). 

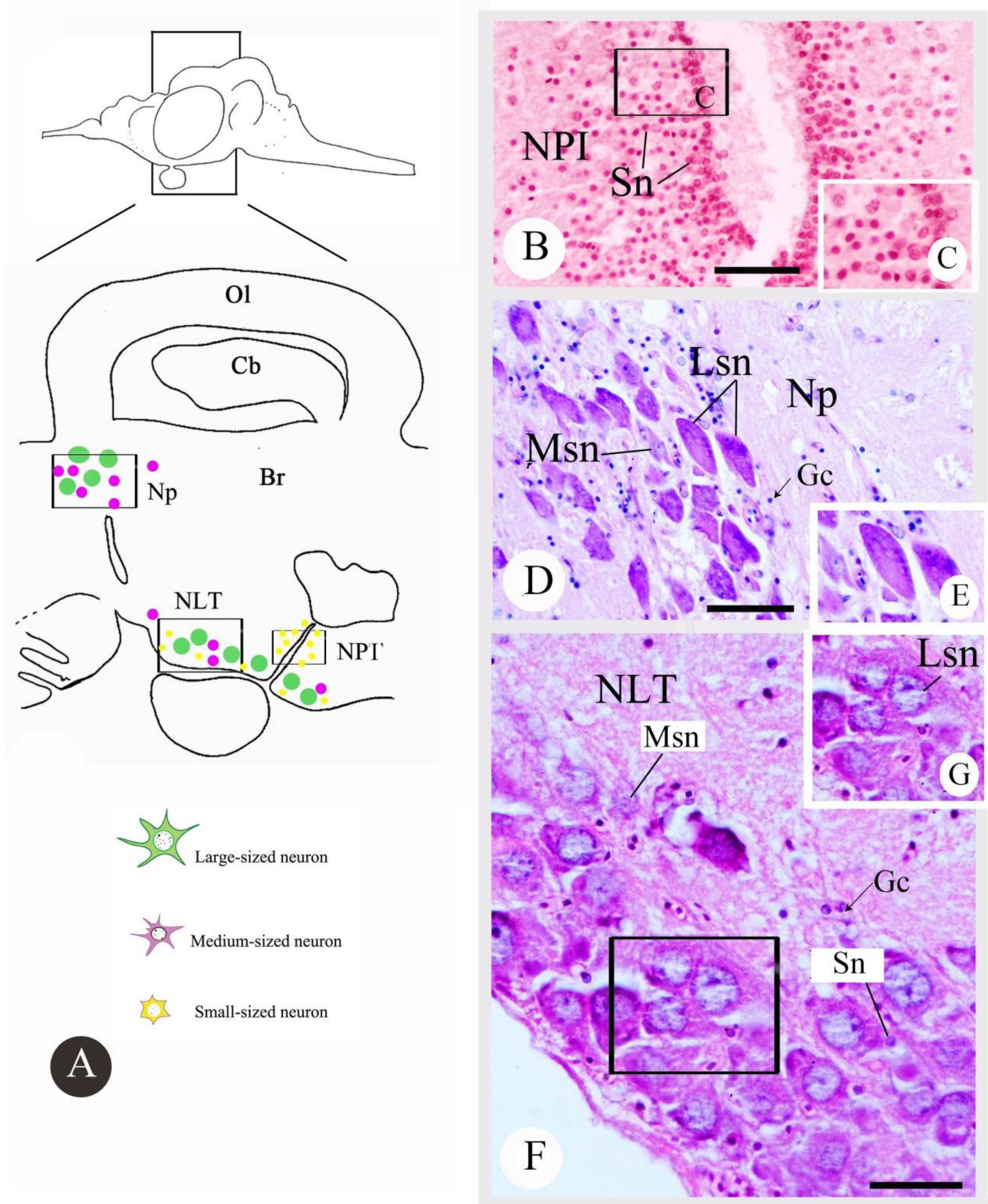

Figure 1. Schematic diagrams of the brain $(\mathrm{Br})(\mathrm{A})$ and light photomicrographs of three nuclei in the diencephalon: nucleus periventricularis (NPI, B-C), nucleus preopticus (Np, D-E) and nucleus lateralis tuberis (NLT, F-G). Sn = small-sized neuron, Msn = medium-sized neuron, Lsn = large-sized neuron. Gc $=$ glial cells, $\mathrm{Ol}=$ optic lobe, $\mathrm{Cb}=$ cerebellum. Scale bar: $50 \mu \mathrm{m}(\mathrm{B}), 100 \mu \mathrm{m}(\mathrm{D}, \mathrm{F})$. 


\section{Hy}
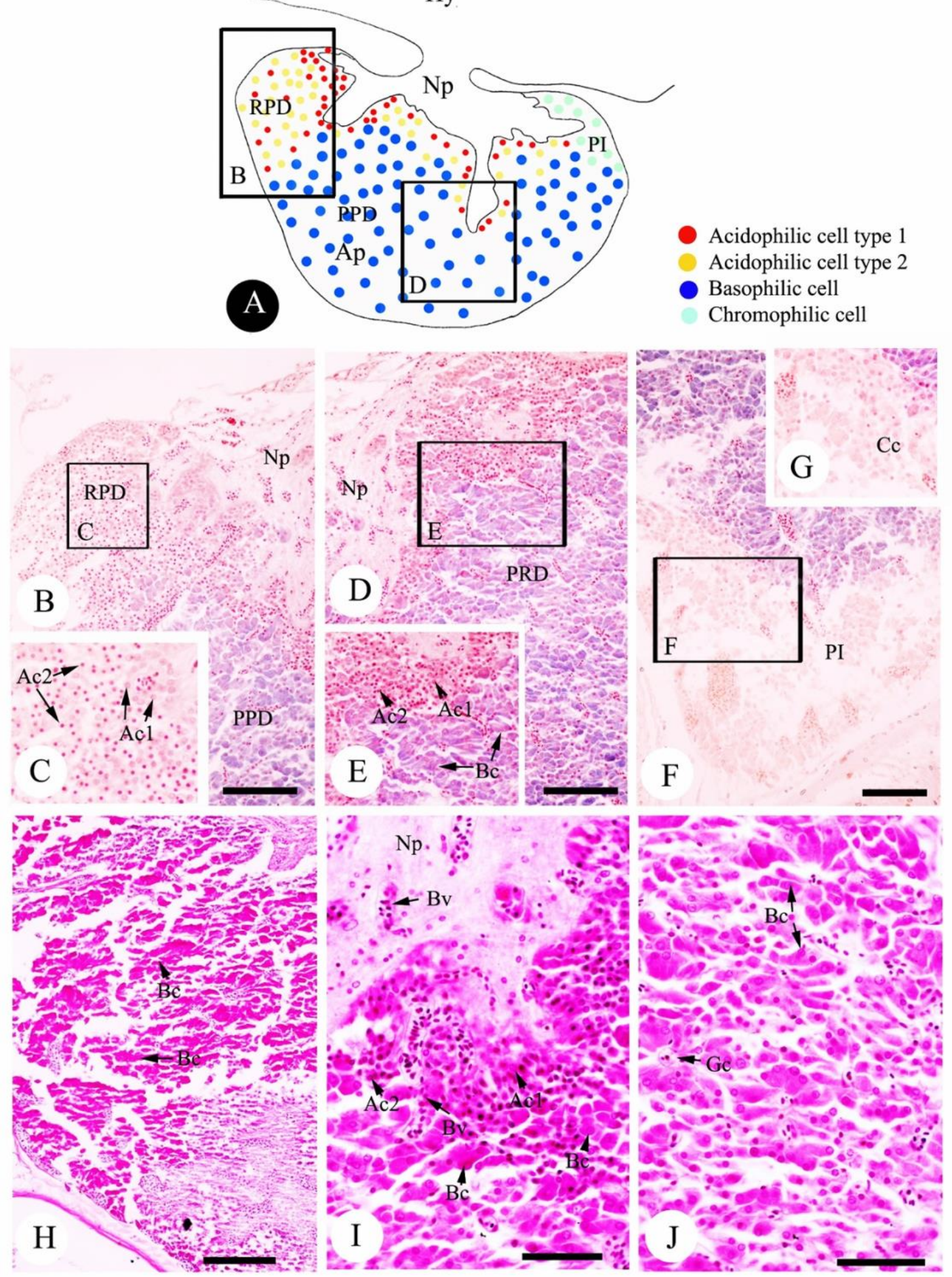

Figure 2. Schematic diagram of the pituitary gland (A) and light photomicrographs of pituitary histology stained using MT (B-F) and $\mathrm{H} \& \mathrm{E}(\mathrm{H}-\mathrm{J})$ with composed of two distinct areas including the adenohypophysis (Ap) and the neurohypophysis (Np). Ac1 = Acidophilic cell type 1, Ac2 = Acidophilic cell type $2, \mathrm{Bc}=$ basophilic cell, $\mathrm{Bv}=$ blood vessel, $\mathrm{Cc}=$ chromophilic cell, $\mathrm{Gc}=$ granular cord, $\mathrm{Hy}=$ hypothalamus, $\mathrm{PI}=$ pars intermedia, $\mathrm{PPD}=$ proximal par distalis, $\mathrm{RPD}=$ rostral pars distalis. Scale bar: $50 \mu \mathrm{m}(\mathrm{B}, \mathrm{D}, \mathrm{F}, \mathrm{H}, \mathrm{I}, \mathrm{J})$. 
Immunohistochemical localization of ER $\alpha$ in the brain. No ER $\alpha$-ir cells were found in the telencephalon (Figure 3A), whereas all other regions (diencephalon, mesencephalon, metencephalon and myelencephalon) tested contained ER $\alpha$-ir cells. In the mesencephalon, intense $E R \alpha$ signals were observed in the cytoplasm of the neurons, while nucleus was only weakly stained (Figures 3B-3C). Dense ER $\alpha$-ir fibers were found in the stratum opticum, stratum fibrosum et griseum superficiale and stratum album centrale of the optic tectum (Figure 3D). The strong expression of ER $\alpha$ in the optic tectum suggests the potential role of estrogen in the visual system, although further study is needed to understand the function. In the diencephalon, strong immunoreactivity was observed in small-, medium- and large-sized neurons of the nucleus lateralis tuberis (Figure 3E).

Immunoreactivity of $\mathrm{ER} \alpha$ in the metencephalon was located in the Purkinje cell layer in both the corpus cerebelli (Figures $3 \mathrm{~F}-3 \mathrm{H}$ ) and valvula cerebelli (Figure 3I). Intense ER $\alpha$ immunoreactivity was also observed in the granular layer of metencephalon (Figure 3G). In addition, the stained structures were dendrites of Purkinje cells in both the valvula cerebelli (Figure 3I) and corpus cerebelli under high magnification (Figures 4A-4C). Lastly, the ER $\alpha$ immunoreactivity was detected in the neurons of the medullar oblongata (Figures 4D-4H) and in the gonadrotropic cells of the pituitary gland (Figures 4F-4G).

\section{Immunohistochemical localization of ERe and $\mathbf{G T H s}$ in $\boldsymbol{R}$. brachysoma ovaries. The} overall histological analysis on the ovary showed that our specimens contained oocytes in several developmental stages, including previtellogenic stage, early vitellogenic stage and late vitellogenic stage (Figure $5 \mathrm{~A}$ ). Weak immunoreactivity of ER $\alpha$ was observed in follicular cells of oocytes in early and late vitellogenic stages (Figure 5B, Table 1). Interestingly, an intense GTHs immunoreactivity was observed in follicular cells of oocytes (Figures $5 \mathrm{C}-5 \mathrm{H})$. The intensity of $\mathrm{LH}$ and FSH immunoreactivities measured by the Digimizer software was generally consistent with visual observation (Figures 5F-5H, Table 1).

Positive and negative controls. For the positive controls, $\mathrm{ER} \alpha$ immunoreactivity was observed in breast cancer sections (Figure 6A). No immunoractivity of $E R \alpha$ was detected in the brain in negative control experiments (Figures 6B-6D). There were no FSH- and LH-ir cells observed in the negative control sections of the ovarian tissue (Figures 6E-6G).

In this study, rabbit polyclonal antisera against $\mathrm{ER} \alpha$ was used for the identification of $\mathrm{ER} \alpha$ in the brain and ovary of $R$. brachysoma with appropriate positive and negative controls described above (see Figure 6). The positive reactions were found in different regions of $R$ brachysoma brain including the diencephalon and the metencephalon (Figures 2-3). These distribution patterns of $E R \alpha$ are quite similar to those in other teleosts, for example Macropodus opercularis (Linnaeus, 1758) (Davis et al., 1977), Carassius auratus Linnaeus, 1758 (Kim et al., 1978) and O. mykiss (Anglade et al., 1994), as well as in higher vertebrates (Morrell et al., 1975), indicating that estrogenic actions take place in the brain of $R$. brachysoma to support the reproductive performance. Specifically, an intense reaction of $\mathrm{ER} \alpha$ was observed in the nucleus preopticus of the diencephalon in this study as also reported in several fish species including O. mykiss (Anglade et al., 1994) and Oryzias latipes (Zempo et al., 2013). It would be of interest to explore whether ER $\alpha$ exerts specific functions in the nucleus preopticus. We also observed intensive $\mathrm{ER} \alpha$ staining in Purkinje cells in the Purkinje layer, in neuronal cells in the granular layer, and some layers of the optic tectum and medullar oblongata. These results identified the potential brain regions involved in the $E_{2}$ pathway for $R$. brachysoma, although further studies are required to explore its function. The localization of ER $\alpha$ in the central and peripheral nervous systems has also been reported in Porichthys notatus (Forlano et al., 2005). 

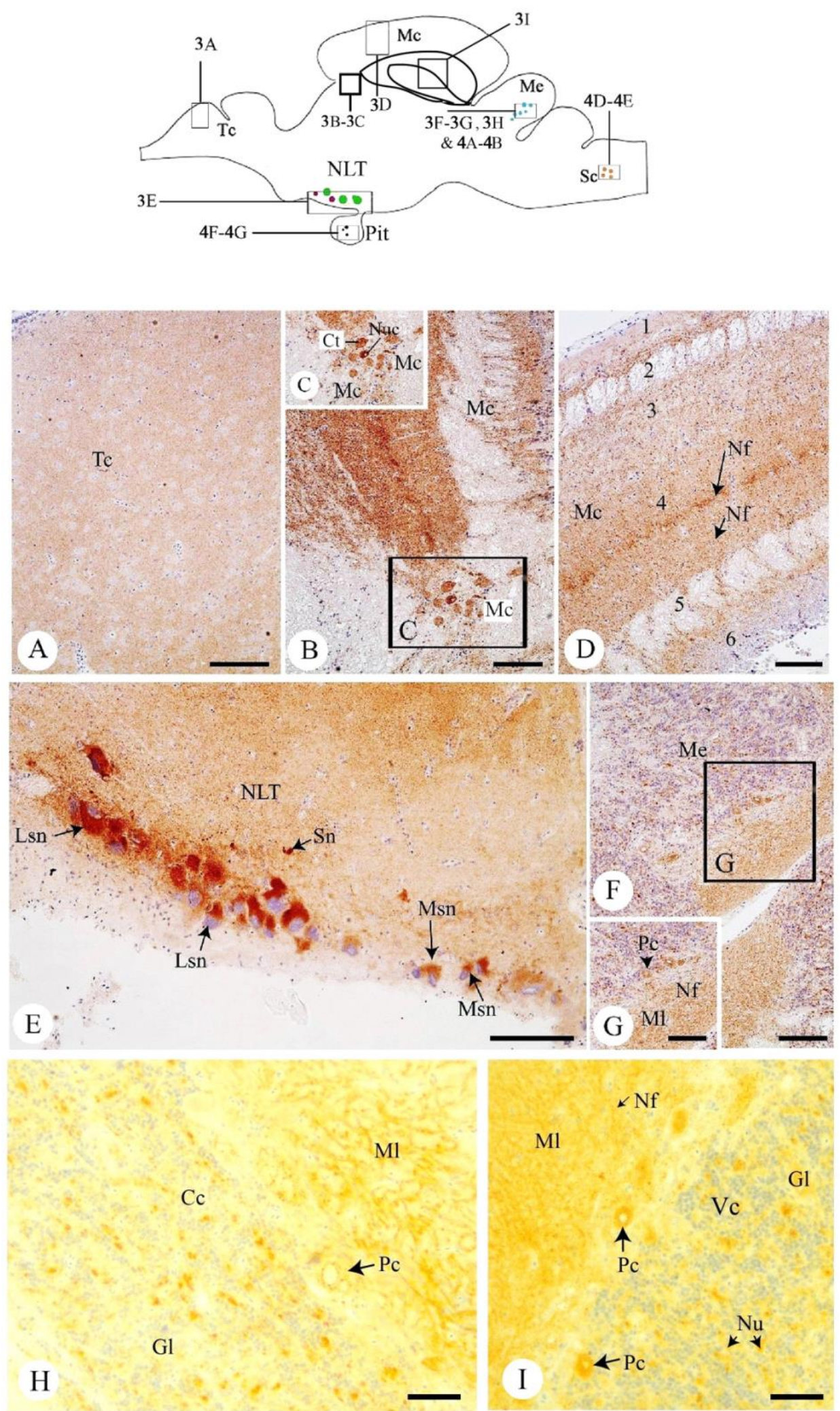

Figure 3. Schematic diagram (upper) and light micrographs of the estrogen receptor $\alpha$ immunoreactivity (lower) of Rastrelliger brachysoma brain. (A) telecephalon, (B-D) mesencephalon, (E) diencephalon, (F-I) metencephalon. 1 = stratum marginale, 2 = stratum opticum, $3=$ stratum fibrosum et griseum superficiale, $4=$ stratum album central, $5=$ stratum griseum central, $6=$ stratum periventriculae, $\mathrm{Cc}=$ corpus cerebelli, $\mathrm{Ct}=$ cytoplasm, $\mathrm{Gl}=$ granular layer, $\mathrm{Mc}=$ mesencephalon, $\mathrm{Ml}=$ molecular layer, $\mathrm{Nf}=$ neuronal fibers, $\mathrm{NLT}=$ nucleus lateralis tuberis, $\mathrm{Nu}=$ neurons, $\mathrm{Nuc}=$ nucleus, $\mathrm{Pc}=$ Purkinje cells, $\mathrm{Po}=$ pre-optic area, $\mathrm{Tc}=$ telencephalon, $\mathrm{Vc}=$ valvula cerebelli. Scale bar, $\mathrm{A}-\mathrm{E}, \mathrm{G}-\mathrm{I}=50 \mu \mathrm{m} ; \mathrm{F}=30 \mu \mathrm{m}$. 

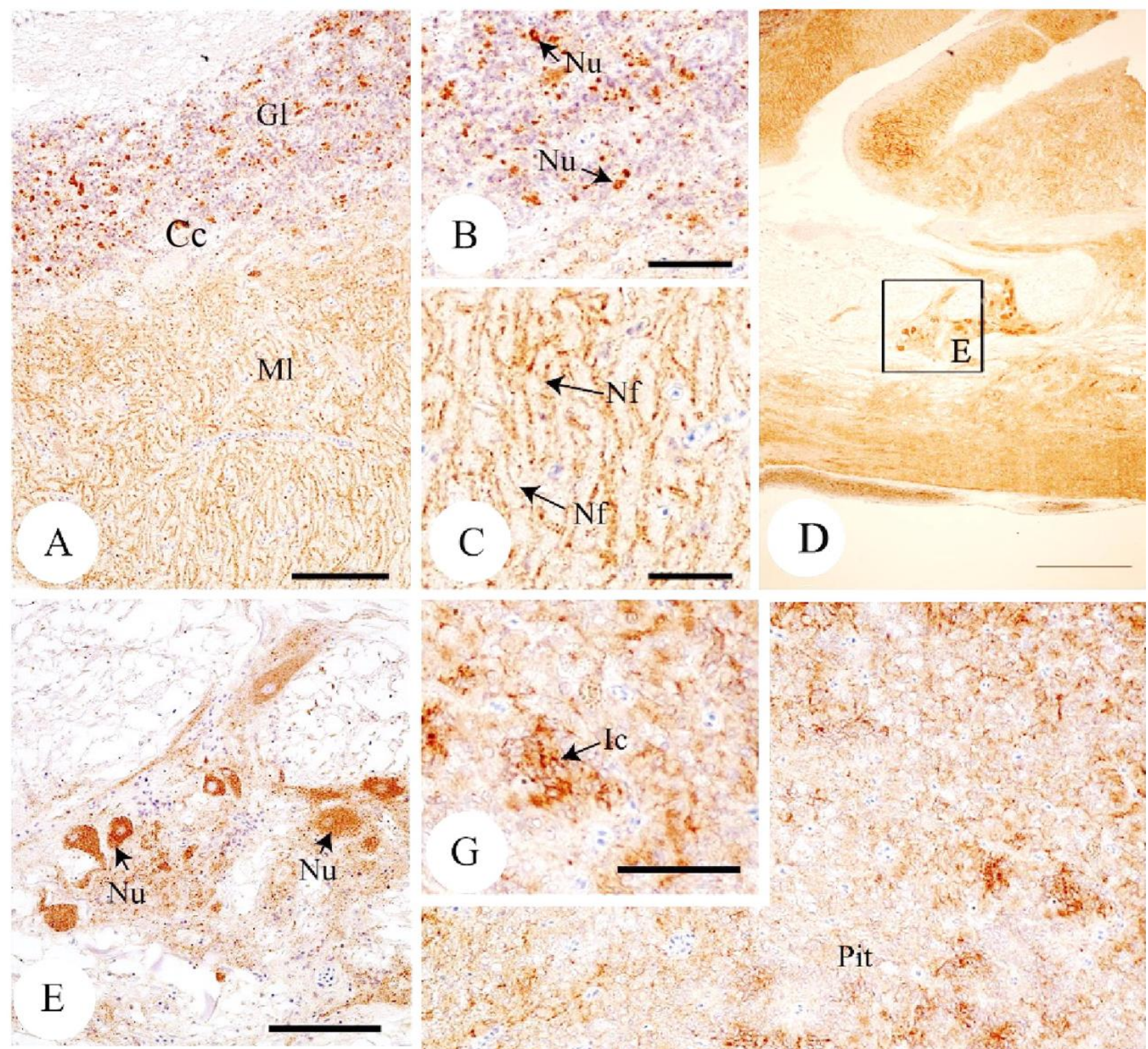

$\mathrm{D}$

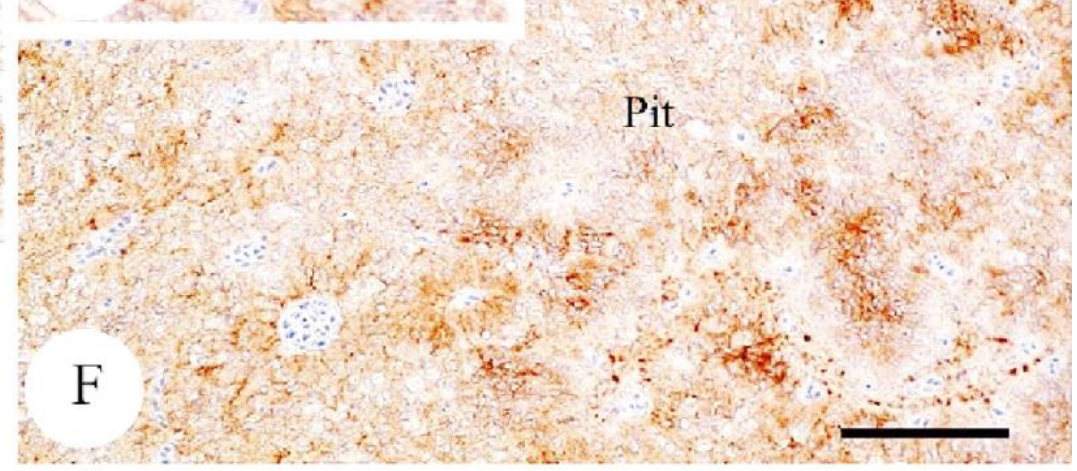

Figure 4. Light micrographs of the distribution of estrogen receptor $\alpha$ immunoreactivity in the metencephalon (A-C), myelencephalon (D-E) and pituitary gland $(\mathrm{F}-\mathrm{G})$ of Rastrelliger brachysoma. $\mathrm{Cc}=$ corpus cerebelli, $\mathrm{Ic}=$ immunoreactive cells, $\mathrm{Gl}=$ granular layer, $\mathrm{Me}=$ myelencephalon, $\mathrm{Ml}=$ molecular layer, $\mathrm{Nf}=$ neuronal fibers, $\mathrm{Nu}=$ neurons, $\mathrm{Pc}=$ Purkinje cells, $\mathrm{Pg}=$ pituitary gland. Scale bar, $\mathrm{H}=200$ $\mu \mathrm{m} ; \mathrm{C}, \mathrm{E}=100 \mu \mathrm{m} ; \mathrm{A}, \mathrm{D}, \mathrm{I}=50 \mu \mathrm{m} ; \mathrm{F}, \mathrm{G}=20 \mu \mathrm{m}$. 


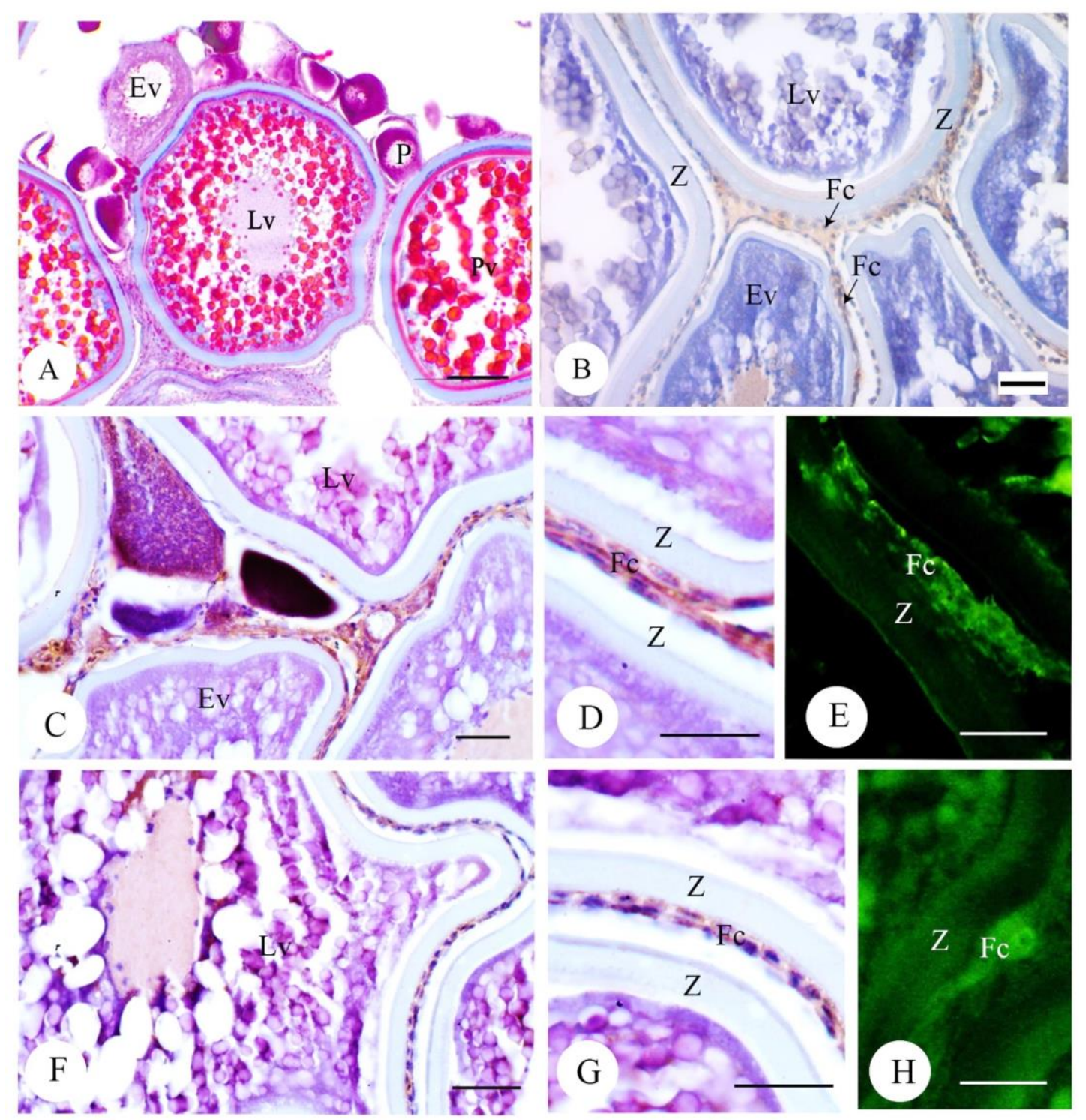

Figure 5. Light photomicrograph showing the ovarian histology stained with MT (A) and ER $\alpha$, FSH and LH immunoreactivities in the ovarian tissue. B: ER $\alpha$; C-E: LH; F-H: FSH. Ev = early vitellogenic stage, $\mathrm{Fc}=$ follicular cell, $\mathrm{Lv}=$ late vitellogenic stage, $\mathrm{P}=$ peirnucleolar stage, $\mathrm{Z}=$ zona pellucida. Scale bar; 20 $\mu \mathrm{m}(\mathrm{A}-\mathrm{H})$.

Table 1. Summary of the presence of ER $\alpha$-ir, LH - ir and FSH - ir in oogenic stages and their follicular cells of Rastrelliger brachysoma.

\begin{tabular}{|c|c|c|c|c|}
\hline \multirow{2}{*}{ Immunoreactivity } & \multicolumn{4}{|c|}{ Steps of oogenic stages and follicular cells } \\
\cline { 2 - 5 } & Oocyte (Ev) & Fc (Ev) & Oocyte (Lv) & Fc (Lv) \\
\hline \multirow{2}{*}{ ER $\alpha$-ir } & & + & & + \\
& - & Weak & - & Weak \\
& & $(0.84 \pm 0.04)$ & & $(0.79 \pm 0.04)$ \\
\hline \multirow{2}{*}{ LH - ir } & + & ++ & + & ++ \\
& Weak & Moderate & Weak & Moderate \\
& $(0.75 \pm 0.17)$ & $(0.67 \pm 0.08)$ & $(0.78 \pm 0.03)$ & $(0.67 \pm 0.08)$ \\
\hline \multirow{2}{*}{ FSH - ir } & + & ++ & + & ++ \\
& Weak & Moderate & Weak & Moderate \\
& $(0.74 \pm 0.05)$ & $(0.61 \pm 0.03)$ & $(0.79 \pm 0.08)$ & $(0.70 \pm 0.11)$ \\
\hline
\end{tabular}

Note- + weak immunoreactivity, ++ moderate immunoreactivity, +++ strong immunoreactivity, - no immunoreactivity $\left(F_{c}=\right.$ follicular cells, $E v=$ early vitellogenic stage, $L v=$ late vitellogenic stage $)$ 


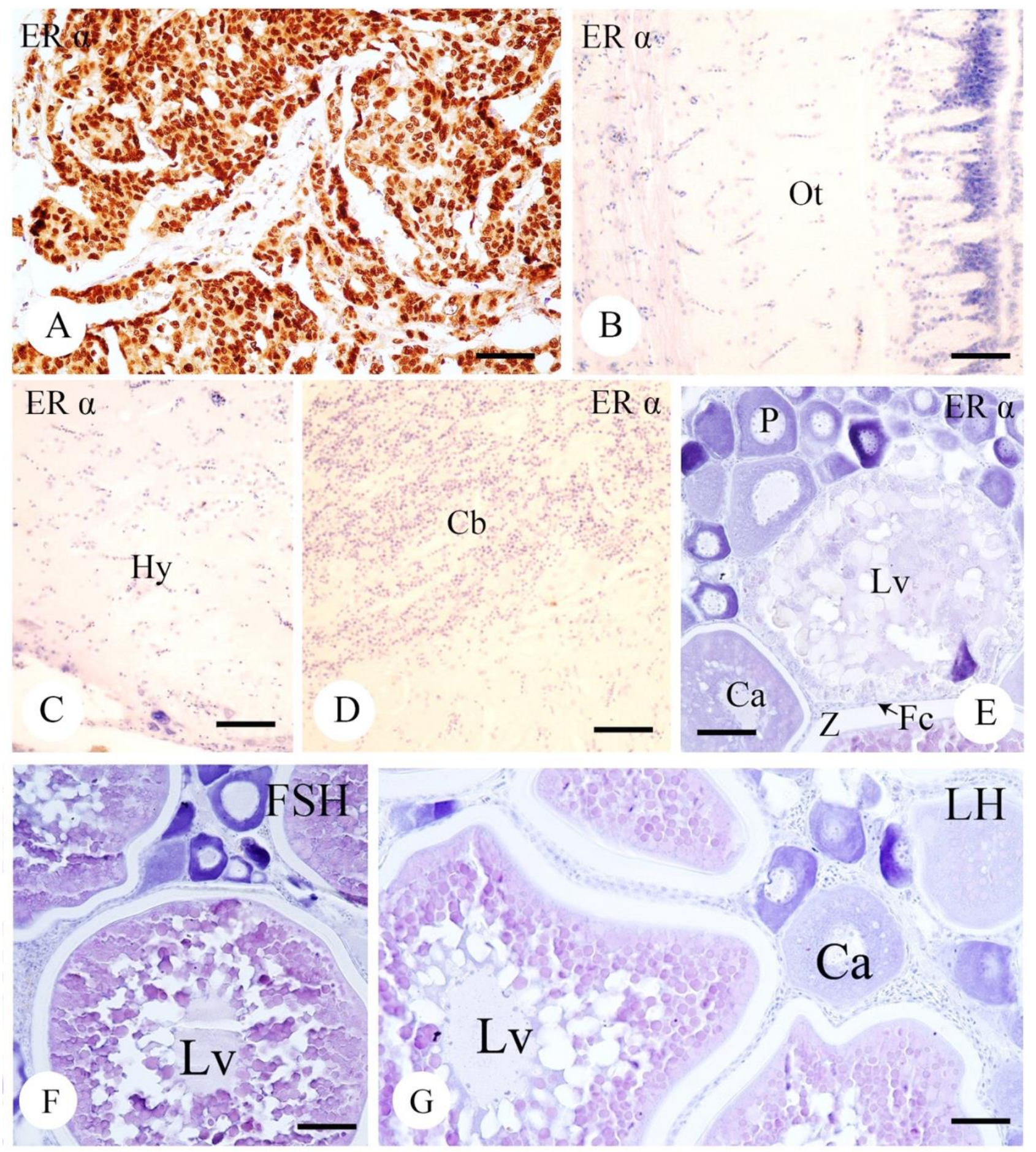

Figure 6. Light photomicrograph showing the positive control of ER $\alpha$ immunoreactivity on breast cancer sections $(\mathrm{A})$ and negative controls $(\mathrm{B}-\mathrm{H}) . \mathrm{Ca}=$ cortical alveoli stage, $\mathrm{Cb}=$ cerebellum, $\mathrm{Fc}=$ follicular cell, $\mathrm{Hy}=$ hypothalamus, $\mathrm{Lv}=$ late vitellogenic stage, $\mathrm{Ot}=$ optic tectum, $\mathrm{P}=$ perinucleolar stage, $\mathrm{Z}=$ zona pellucida.

In vertebrates, $\mathrm{E}_{2}$ has multifunctional roles such as gonadal development and uptake of vitellogenin into the oocytes (Gustafsson, 2003; Hess, 2003; Heldring et al., 2007). Our current and previous (Senarat, 2015) results suggest that $\mathrm{E}_{2}$ also functions in the brain, possibly in relation to $\mathrm{GnRH}$ release, because $\mathrm{ER} \alpha$ immunoreactivity was detected in the sbGnRH-ir cells. Although there are few reports regarding the physiological roles of this colocalization (Forlano et al., 2005; 
Oakley et al., 2009), the existence of the $E_{2}$ feedback to $\mathrm{GnRH}$-producing cells has been proposed. It is currently difficult to figure out whether the feedback is positive or negative (Sower, 2005; Oakley et al., 2009; Kenealy and Terasawa, 2012), but the involvement of GABA and/or Kisspeptide has been also proposed as the mechanism for the interaction of $E_{2}$ and $\mathrm{GnRH}$ (Sower and Baron, 2005). In further works, it would be of interest to investigate the colocalization of GABA, GnRH, kisspeptin and ER in the brain to determine the consequences of their interactions.

Another important observation of the current work relates to the moderate immunoreactivity of $\mathrm{LH}$ and FSH detected in the follicular cells in vitellogenic stages compared to those in early oocyte differentiation stages (i.e., oogonia to lipid and cortical alveloli stage). These results are consistent with a previous hypothesis that FSH, but not LH, stimulates vitellogenin uptake to follicular cells in rainbow trout (Nagahana, 1994). FSH is also considered to be involved in the testosterone synthesis and its conversion to $\mathrm{E}_{2}$ by aromatase in follicular cells, which further stimulates the final oocyte maturation. We assume that $\mathrm{ER} \alpha, \mathrm{FSH}$ and $\mathrm{LH}$ coordinately control the oocyte maturation in $R$. brachysoma ovary. However, this hypothesis needs to be tested in future studies that employ detailed observation of the activity and expression levels of enzymes involved. It is also important to use $R$. brachysoma specimens of various maturation stages since the present study used only those in the spawning season.

In this study, we demonstrated the immunolocalization of $E R \alpha$ in the brain of $R$. brachysoma, which indicates that the brain is one of the target organs of estrogens. We also detected $\mathrm{ER} \alpha$ and GTHs (FSH and LH) in the follicular cells in the ovary of $R$. brachysoma. To our knowledge, this is the first clear-cut evidence of GTHs-ER $\alpha$ expression in follicular cells, which suggests that follicular cells have a more complicated function than previously thought. Detailed functional analyses on follicular cells will help us understand the reproductive physiology of R. brachysoma.

\section{ACKNOWLEDGMENTS}

The authors would like to express their sincere appreciation to the Rachadapisek Sompote Fund for Postdoctoral Fellowship, Chulalongkorn University and The $100^{\text {th }}$ Anniversary Chulalongkorn University Fund for Doctoral Scholarship for their financial support to carry out this research.

\section{REFERENCES}

Auchus, R. J. \& Fuqua, S. A. W. 1994. The estrogen receptor. Bailliere's Clinical Endocrinology and Metabolism 8: 433-449.

Anglade, I., Pakdel, F., Bailhache, T., Petit, F., Salbert, G., Jego, P., Valotaire, Y., \& Kah, O. 1994. Distribution of estrogen receptor-immunoreactive cells in the brain of the rainbow trout (Oncorbynchus mykiss). Journal of Neuroendocrinology 6: 573-583.

Bancroft, J. D. \& Gamble, M. 2008. Theory and practice of histological techniques. Elsevier Health Sciences.

Bouma, J. \& Nagler, J. J. 2001. Estrogen receptor- $\alpha$ protein localization in the testis of the rainbow trout (Oncorbynchus mykiss) during different stages of the reproductive cycle. Biology of Reproduction 65: 60-65.

Davis, R. E., Morrell, J. I., \& Pfaff, D. W. 1977. Autoradiographic localization of sex-steroid concentrating cells in the brain of the teleost Macropodus opercularis (Osteichthyes: Belontiidae). General and Comparative Endocrinology 33: 496-505.

Dietrich, D. \& Krieger, H. O. 2009. Histological analysis of endocrine disruptive effects in small laboratory fish. John Wiley \& Sons.

Forlano, P. M., Deitcher, D. I., \& Bass, A. H. 2005. Distribution of estrogen receptor alpha mRNA in the brain and inner ear of a vocal fish with comparisons to sites of aromatase expression. Journal of Comparative Neurology 483: 91-113.

Fukumoto, T., Tawa, M., Yamashita, N., Ohkita, M., \& Matsumura, Y. 2013. Protective effects of 17beta-estradiol on postischemic cardiac dysfunction and norepinephrine overflow through the non-genomic estrogen receptor/nitric oxide-mediated pathway in the rat heart. European Journal of Pharmacology 699: 74-80.

Gieske, M. C., Kim, H. J., Legan, S. J., Koo, Y., Krust, A., Chambon, P., \& Ko, C. 2008. Pituitary gonadotroph estrogen receptor- $\alpha$ is necessary for fertility in females. Endocrinology 149: 20-27.

González-Martínez, D., Madigou, T., Zmora, N., Anglade, I., Zanuy, S., Zohar, Y., Elizur, A., Muñoz-Cueto, J. A., \& Kah, O. 2001. Differential expression of three different prepro-GnRH (gonadotrophin-releasing hormone) messengers in the brain of the european sea bass (Dicentrarchus labrax). Journal of Comparative Neurology 429: 144-155.

González-Martínez, D., Zmora, N., Mañanos, E., Saligaut, D., Zanuy, S., Zohar, Y., Elizur, A., Kah, O., \& Muñoz-Cueto, J.A. 2002. Immunohistochemical localization of three different prepro-GnRHs in the brain and pituitary of the European sea bass (Dicentrarchus labrax) using antibodies to 
the corresponding GnRH-associated peptides. Journal of Comparative Neurology 446: 95-113.

Gothilf, Y., Meiri, I., Elizur, A., \& Zohar, Y. 1997. Preovulatory changes in the levels of three gonadotropin-releasing hormone-encoding messenger ribonucleic acids (mRNAs), gonadotropin beta-subunit mRNAs, plasma gonadotropin, and steroids in the female gilthead seabream, Sparus aurata. Biology of Reproduction 57: 1145-1154.

Guilgur, L. G., Moncaut, N. P., Canário, A. V., \& Somoza, G. M. 2006. Evolution of GnRH ligands and receptors in gnathostomata. Comparative Biochemistry and Physiology - Part A: Molecular \& Integrative Physiology 144: 272-283.

Gustafsson, J. A. 2003. What pharmacologists can learn from recent advances in estrogen signaling. Trends in Pharmacological Sciences 24: 479-485.

Hara, A., Hiramatsu, N., \& Fujita, T. 2016. Vitellogenesis and choriogenesis in fishes. Fisheries Science 82: 187-202.

Heldring, N., Pike, A., Andersson, S., Matthews, J., Cheng, G., Hartman, J., Tujague, M., Ström, A., Treuter, E., Warner, M., \& Gustafsson, J. A. 2007. Estrogen receptors: how do they signal and what are their targets. Physiological Reviews 87: 905-931.

Hess, R. A. 2003. Estrogen in the adult male reproductive tract: a review. Reproductive Biology and Endocrinology 1: 52.

Huggard-Nelson, D. L., Khakoo, Z., Kassam, G., Mahmoud, S. S., \& Habibi, H. R. 1996. Effect of testosterone on maturational gonadotropin subunit messenger ribonucleic acid levels in the goldfish pituitary. Biology of Reproduction 54: 1184-1191.

Huggard-Nelson, D. L., Nathwani, P. S., Kermouni, A., \& Habibi, H. R. 2002. Molecular characterization of LH-beta and FSH-beta subunits and their regulation by estrogen in the goldfish pituitary. Molecular and Cellular Endocrinology 188: 171-193.

Kenealy, B. P. \& Terasawa, E. 2012. Rapid direct action of estradiol in $\mathrm{GnRH}$ neurons: findings and implications. Frontiers in Endocrinology 2: 1-6 .

Kim, Y. S., Stumpf, W. E., \& Sar, M. 1978. Topography of estrogen target cells in the forebrain of goldfish, Carassius auratus. Journal of Comparative Neurology 182: 611-620.

Liu, T., Liu, S., Ma, L., Li, F., Zheng, Z., Chai, R., Hou, Y., Xie, Y., \& Li, G. 2017. Oogenesis, vitellogenin-mediated ovarian degeneration and immune response in the annual fish Nothobranchius guentheri. Fish and Shellfish Immunology 66: 8692.

Morrell, J. I., Kelley, D. B., \& Pfaff, D. W. 1975. Sex steroid binding in the brain of vertebrates: Studies with light microscopic autoradiography. In: The Ventricular System in Neuroendocrine Mechanism. Ed. Knigge, K.M., Scott, D.E. and Kobayashi, M. pp 230-256. Proceeding of the Second Brain-Endocrine Interaction Symposium, Karger, Basel.

Nagahama, Y. 1994. Endocrine regulation of gametogenesis in fish. The International Journal of Developmental Biology 38: $217-$ 217.

Nagler, J. J., Cavileer, T. D., Verducci, J. S., Schultz, I. R., Hook, S. E., \& Hayton, W. L. 2012. Estrogen receptor mRNA expression patterns in the liver and ovary of female rainbow trout over a complete reproductive cycle. General and Comparative Endocrinology 178: 556-561.

Oakley, E., Clifton, D. K., \& Steiner, R A. 2009. Kisspeptin signaling in the brain. Endocrinological Reviews 30: 713-743.

Palevitch, O., Abraham, E., Borodovsky, N., Levkowitz, G., Zohar, Y., \& Gothilf, Y. 2009. Nasal embryonic LHRH factor plays a role in the developmental migration and projection of gonadotropin-releasing hormone 3 neurons in zebrafish. Developmental Dynamics 238: 66-75.
Palmieri, G., Acone, F., Desantis, S., Corriero, A., Ventriglia, G., Addis, P., Genovese, S., Aprea, A., Spedicato, D., \& Losurdo, M. 2008. Brain morphology and immunohistochemical localization of the gonadotropinreleasing hormone in the bluefin tuna, Thunnus thynnus. European Journal of Histochemistry 52: 19.

Peter, R., Crim, L., \& Billard, R. 1991. A stereotaxic atlas and implantation technique for nuclei of the diencephalon of Atlantic salmon (Salmo salar) parr. Reproduction Nutrition Development 31: 167-186.

Qasim, B. J., Ali, H. H., \& Hussein, A. G. 2001. Immunohistochemical expression of estrogen and progesterone receptors in human colorectal adenoma and carcinoma using specified automated cellular image analysis system: A clinicopathological study. Oman Medical Journal 26:307-14.

Radovick, S., Levine, J. E., \& Wolfe, A. 2012. Estrogenic regulation of the GnRH neuron. Frontiers in Endocrinology 3: 1-11.

Sabo-Attwood, T., Kroll, K. J., \& Denslow, N. D. 2004. Differential expression of largemouth bass (Micropterus salmoides) estrogen receptor isotypes alpha, beta, and gamma by estradiol. Molecular and Cellular Endocrinology 218: 107-118.

Selvaraj, S., Kitano, H., Fujinaga, Y., Amano, M., Takahashi, A., Shimizu, A., Yoneda, M., Yamaguchi, A., \& Matsuyama, M. 2009. Immunological characterization and distribution of three GnRH forms in the brain and pituitary gland of chub mackerel (Scomber japonicus). Zoological Science 26: 828-839.

Senarat, S., Kettratad, J., Kangwanrangsan, N., Jiraungkoorskul, W., F. Gerald, Plumley., Amano, M., Shimiza, A., \& Tipdomrongpong, S. 2019. The sbGnRH - GTH system in the female short mackerel, Rastrelliger brachysoma (Bleeker, 1851), during breeding season: implications for low gamete production in captive broodstocks. Fish Physiology and Biochemistry 45: 1-18.

Senarat, S. 2015. Structure and alteration of gonadotropin releasing hormone -1 peptidergic neuronal system during breeding season of short mackerel, Rastrelliger brachysoma (Bleeker, 1851) from Sumut Sonkhram University. Ph D. thesis, Chylalongkorn University.

Senarat, S., Jiraungkoorskul, W., \& Kettratad, J. 2016. Neuroanatomical-histology of the central nervous system in short mackerel, Rastrelliger brachysoma (Bleeker, 1851). Walailak Journal of Science and Technology 13: 531-541.

Shimizu, A., Tanaka, H., \& Kagawa, H. 2003. Immunocytochemical applications of specific antisera raised against synthetic fragment peptide of mummichog $\mathrm{GtH}$ subunits: examining seasonal variations of gonadotrophs (FSH cells and LH cells) in the mumichog and applications to other acanthopterygian fishes. General and Compative Endocrinology 132: 35- 45.

Sower, S. A. \& Baron, M. 2005. The interrelationship of estrogen receptor and $\mathrm{GnRH}$ in a basal vertebrate, the sea lamprey. Frontier of Endocrinology 2: 1-8.

Tsai, M. J. \& O'Malley, B. W. 1994. Molecular mechanisms of action of steroid/thyroid receptor superfamily members. Annual Review of Biochemistry 6: 3451-486.

Uribe, M. C., Grier, H. J., \& Parenti, L. R. 2012. Ovarian structure and oogenesis of the oviparous Goodeids Crenichthys baileyi (Gilbert, 1893) and Empetrichthys latos Miller, 1948 (Teleostei, Cyprinodontiformes). Journal of Morphology 273: 371-387.

Wilson, J. M., Bunte, R. M., \& Carty, A. J. 2009. Evaluation of rapid cooling and tricaine methanesulfonate (MS222) as methods of euthanasia in zebrafish (Danio rerio). Journal of the American Association for Laboratory Animal Science 48: 785-789.

Yan, H. Y. \& Thomas, P. 1991. Histochemical and immunocytochemical identification of the pituitary cell 
types in three sciaenid fishes: Atlantic croaker (Micropogonias undulatus), spotted seatrout (Cynoscion nebulosus), and red drum (Sciaenops ocellatus). General Comparative and Endocrinology 84: 389-400.

Zempo, B., Okubo, K., Kanda, S., \& Oka, Y. 2013. Anatomical distribution of sex steroid hormone receptors in the brain of female medaka. Journal of Comparative Neurology 521: 17601780 . 